\title{
Dr Oepke Noordmans (1871-1956): His contribution to ecclesiology and canon law
}

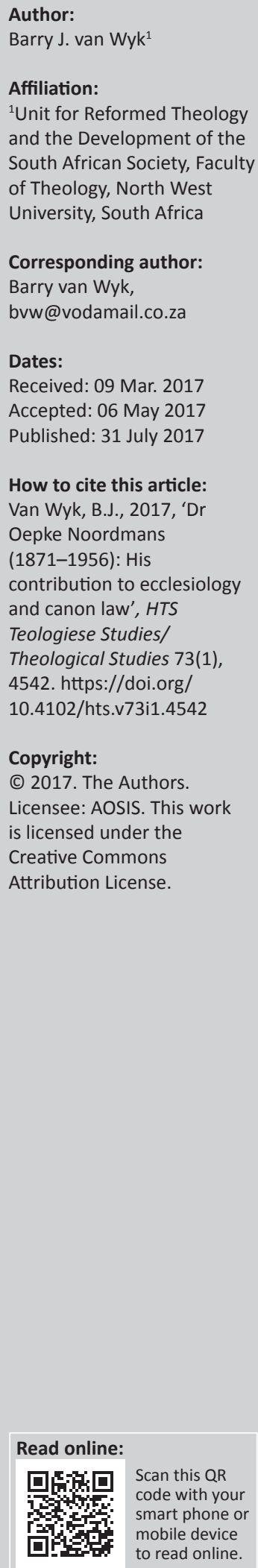

\begin{abstract}
Noordmans was a minister of the Nederlandse Hervormde Kerk and made a substantial contribution to the theological debate in and outside his church. His work reflects his wide theological interest in various disciplines like dogmatics and canon law, but also in philosophy, phenomenology and as 'homme de lettres'. His contribution to canon law is of exceptional interest with specific reference to his Christological ecclesiology and his conviction that proper knowledge of the church according to Scripture is a precondition for church ordinance. He also played a substantial role in the process of his church to decide on a new church order.
\end{abstract}

\section{Inleidend}

Oepke Noordmans wat in 1956 oorlede is, was in sy lewe predikant van die Nederlandse Hervormde Kerk. Hy is gebore in die jaar 1871 te Oosterend, in die gemeente Hennaarderadeel, bekend as die Friese weidegebied. Hy sterf op Sondag 05 Februarie 1956 en word na 'n roudiens op 09 Februarie in Laren begrawe (vgl. Haarsma 1967:10). Sy vriend ds. W.A. Zeydner het die roudiens waargeneem aan die hand van Jeremia 9:23 en 24: ${ }^{1}$

So sê die Here: Die wyse man moet nie in sy wysheid roem nie, die soldaat nie in sy krag nie, die ryk man nie in sy rykdom nie. Laat hom wat wil roem, daarin roem dat hy insig het en My ken. Ek is die Here. Ek bewys liefde, reg en geregtigheid op die aarde, want dit is wat Ek wil hê, sê die Here. (Noordmans 1999b:1011; Paul 1959:31)

Die opmerking sou dalk volg dat die tekskeuse ietwat ongewoon is en eerder vervang sou kon word met 'n gedeelte uit die Nuwe Testament, veral in die tye waarin vandag geleef word. Maar miskien kan dit gesien word as 'n keuse wat die besondere aard en mens wat Noordmans was, verwoord het. Gewoon op die oog af was hy 'n besonder produktiewe teoloog wat, veral as 'n gemeente-predikant, homself ook op akademiese gebied onderskei het soos blyk uit sy versamelde werke wat uit tien dele bestaan waardeur Noordmans se teologie, sy kerklike denke, asook sy menswees, veral uit sy briewe, toeganklik is. Die vooruitskouing van Hasselaar (1958:5) was nie vergesog nie dat Noordmans se 'getuigenis en polemiek in het centrum van de essentiële hervormde en oecumenische probleemstellingen, zullen met de tijd aan kracht winnen'.

Tydens sy doctor honoris causa-promosie (1935) word sy verdienste as teoloog erken in die woorde van sy promotor prof. W.J. Aalders:

Elke stof zoekt vorm. Edel goud wil gemunt worden. Daarom acht ik het een voorrecht, dat wij uw wetenschappelijke verdiensten op deze wijze kunnen erkennen. Deze hulde schept niet wat niet is, maar erkent wat is. (Haarsma 1967:5)

\section{Biografiese gegewens}

Oepke Noordmans is een van drie seuns uit die huwelik tussen Durk Piers Noordmans en Gerbrig Oepkes de Roos, komende uit 'n Franse refugié-familie. Hoewel sy vader 'n boer was, het hy 'n besondere belangstelling getoon in die geskrifte van Da Costa, Groen van Prinsterer, Wormser, asook De Clerq. Die name van ander figure uit die Réveil soos Capadose en Keuchenius was eweneens aan hom bekend. Die opvoeding in die huis van Noordmans se vader kan as streng puriteins tipeer word. Noordmans skryf aan Wumkes en stel dat 'alle meer uitgelaten vrolijkheid, elk ruw woord, zelfs elk sterk woord' deur die puriteinse lewensopvatting en religieuse tug geweer is. 'Ik herinner mij niet ooit iets, wat hierop leek, bij hem gezien of gehoord te hebben'. Noordmans se vader begin met 'n boerdery in Tzum, waar hy ook daaraan meewerk om 'n Christelike skool op te rig, soos wat later ook in Oosterend gebeur. Wanneer die Doleansie ter sprake kom, maak hy 'n keuse 1.1983 vertaling van die Bybelgenootskap van Suid-Afrika, 1991. 
vir die religieus-etiese denke van Hoedemaker teenoor die meer skolastiese opvattings van Kuyper (Noordmans 1999a:279-280).

Noordmans verwoord in die brief aan Wumkes sy verbasing hoe die 'contemporaine historie' vanuit sy ouerhuis gevolg en beleef is. Die gedagtes van Wormser oor die doop was vir hom gesaghebbend en dit is duidelik dat die gesin kerklik betrokke was, soos Noordmans dit stel: 'In de doleantiedagen waren we allemaal wat vroegrijp kerkelijk'. Noordmans se vader was inderdaad ook in die gemeente betrokke en het op die kerkraad gedien soos blyk uit die feit dat hy soms begrafnisdienste waargeneem het wanneer die plaaslike predikant afwesig was. Sy vader was ook betrokke as wethouer van Wymbritseradeel (vgl. Wassenaar 1989:16), lid van die provinsiale kerkbestuur, en beskik oor wat Noordmans noem 'n otium cum dignitate (rus met waardigheid). Hy trek hom op 12 Mei 1902 terug uit sy boerdery en sterf op 12 Desember 1907, om in Oosterend begrawe te word (Noordmans:1999a:280-281).

Die indruk wat Psalm 24 op die sesjarige Noordmans gelaat het wat hy op pad skool toe leer, kan dalk as 'n voorteken beskou word op wat later in sy lewe gevolg het (Noordmans 1990:103). Hy het besondere waardering vir sy ouerhuis gekoester wat vir hom soos 'n huiskerk was, rigtinggewend vir die res van sy lewe. In die laerskool van Scharnegoutum was dit veral meester Langhout, wat 'n besondere bydrae tot sy vorming lewer en sy vader oortuig het dat dit nie noodwendig is dat Noordmans sy vader in sy boerdery moes opvolg nie. Sy verdere skoolonderrig voltooi hy aan die hoërskool van Zetten. Vanweë die Doleansie ag sy ouers dit goed om hom te verskuif na die stedelike gimnasium vanSneek waar hy die eindeksamen in 1891 aflê. Die gevolge van die Doleansie laat niemand onaangeraak nie, soos afgelei kan word uit sy vermelding dat sy gesin wat die nawas van die Réveil vertoon, deur die lees van die sogenaamde oude schrijvers, ingesluit Groen van Prinsterer en Kuyper, nie daaraan ontkom het nie (Noordmans 1988:107; Paul 1959:17-19).

In 1891 begin Noordmans sy teologiese studie aan die Ryksuniversiteit van Leiden waar hy sy propaedeutische examen aflê. Hier maak hy kennis met die toe bekende $\mathrm{Ou}$ Testamentikus, prof. Keunen, ookmet diegodsdienshistorikus prof. Thiele, maar dit was veral die ontmoeting met prof. J.H. Gunning (snr) wat 'n lewenslange invloed op hom uitoefen, soos hy dit beskryf:

de diepzinnige en vrome rede, waarmee de cursus geopend werd; de lessen, die tegelijk Evangeliebediening waren; het ziekenbezoek op de studentenkamer; die toegestoken hand op de studeerkamer van de professor, neen, de beide handen waartussen de mijne genomen werd. (Noordmans 1981:342)

Hy koester ook besondere dank aan sy Leidse pastor, dr J.H. Gunning Jnr, by wie hy tydens Paasfees 1892 belydenis van geloof doen, en wat in onderskeiding van sy vader, die professor, lewenslank vir hom dominee Gunning gebly het (Noordmans 1988:292).
Vanweë spanning wat hom jare lank kasty, moes hy na 'n jaar sy studie by Leiden onderbreek om eers in 1898 sy teologiese studie voort te sit aan die Ryksuniversiteit van Utrecht waar hy in 1902 die candidaats- en kerkelijk examen aflê, gevolg deur die proponentseksamen voor die provinsiale kerkbestuur van Utrecht, sodat hy beroepbaar gestel kon word (Haarsma 1967:2). In die memoriam deur sy vriend ds W.A. Zeydner meld hy dat Noordmans in een van die laaste gesprekke met hom verwys het na sy moeilike jare as student. 'Verzwakt door te grote lichamelijke inspanningen in zijn gymnasiumtijd, heeft Noordmans als student tijden van grote overspanning doorworsteld' (Noordmans 1999b:1009; vgl. Paul 1959:20).

Die Noordmans-gesin is ook soos ander Nederlanders erg geraak deur die gevolge van die Tweede Wêreldoorlog (1939-1945), sy verpligte emeritaat en gevolglike afskeid van die gemeente Laren (Noordmans 1999b:987), ook boonop die verlies van sy oudste seun soos blyk in 'n brief aan prof. K.H. Miskotte (Noordmans 1999b):

Mijn overleden zoon was een abnormaal gesloten persoonlijkheid, een uiterst fijngevoelige, in voorname gereserveerdheid zich terugtrekkende figuur, die de grofheid miste, die er bijwijlen nodig is, om in deze wereld te verkeren. De behoefte aan fijnheid en zuiverheid van zulke naturen is onverzadigbaar en het blijft voor ons levenslang een schrijnend leed, als wij hem ons in herinnering terugroepen, kennelijk onvoldaan over wat het leven bood. (p. 773)

Tog hou hy'n bruikbare standpunt ná met betrekking tot ouer word. Oues van dae hoef nie te kla omdat hulle lewe verby is nie (Noordmans 1990):

Dan ziet hij terug op dat voorbije leven en zou het eigenlijk nog eens willen beginnen ... Zo 'n leven, dat is levend begraven worden, want ieder jaar dat voorbij gaat, is een plank aan uw doodskist. (p. 62)

Vir hom is die lewe van ' $n$ Christen anders, soos 'n bergklimmer wat hoe verder, al meer win aan uitsig deur 'n al ruimer wordende horison waardeur alle grense vervaag en insig volg. 'Voor de gelovige wordt de doodskist niet getimmerd, maar afgebroken' (Noordmans 1990:62).

Noordmans toon heel vroeg belangstelling in akademiese studie, aangesien hy naas die verpligte stof soos voorgeskryf hom ook verdiep in die godsdiens van Israel en dogmengeskiedenis met die voorneme om na voltooiing van sy studie in die pastorie, aandag aan die etiek te gee. 'Maar gezellige collega's, het edele schaakspel en meerstemmige muziek brachten mij voorlopig daarvan af'. Hy laat egter nie na om verder te studeer nie en wy hom veral aan 'de grote wereldlijke en kerkelijke schrijuers' (Noordmans 1988:15).

By die geleentheid van sy doctor honoris causa by die Universiteit van Groningen op 16 Oktober 1935 (Noordmans 1988:17), stel hy ook dat sy teologie ingebed is in wat hy noem 'de schoot der vroomheid' (Noordmans 1988:15) waarin hy nie allereers aan die kerk as instituut dink nie, maar aan die kerk as moeder. Noordmans se vader Durk Piers groei op in die piëtistiese sfeer van die Franse Réveil en 
dit loop daarop uit dat Noordmans se puriteinse opvoeding bepalend was vir die res van sy lewe.

De Schrift leerde ik kennen viva voce gelezen en niet als palimpsest. $^{2}$ De mystieke tonen van psalmen en gezangen streken over het bewogen leven. Het gebed was geen formulier maar gemoduleerd, zoals het de Geest gaf uit te spreken. Rondom de huiskerk was de hele levenssfeer in beweging. (Noordmans 1988:15, 17)

Op 01 Februarie 1903 word Noordmans op een-en-dertigjarige leeftyd deur sy swaer ds. H.C. Lambers in sy eerste gemeente Idsegahuizen en Piaam bevestig, nadat hy in 1902 deur die provinsiale kerkbestuur van Utrecht toegelaat is tot die evangeliebediening. Sy volgende gemeente is Suameer, geleë op die water- en bosryke sandgrond van Friesland waarin hy deur sy aanstaande skoonvader ds. J. Oosterhuis op 10 Julie 1910 bevestig word. Hier sou hy ruimskoots twaalf en 'n half jaar werksaam wees voor hy op 25 Maart 1923 deur ds. T.J. Jansen Schoonhoven van Almen in sy derde gemeente Laren in Gelderland bevestig is (Noordmans 1999b:1009; Paul 1959:20, 23, 25; vgl. Haarsma 1967:3-5).

Gedurende die jare twintig en dertig bereik Noordmans se voordragte en publikasies ' $n$ vlak wat aan hom 'n besondere plek onder hervormde teoloë in die Nederlandse Hervormde Kerk sou besorg. Hy speel 'n belangrike rol in die invoer en kritiese verwerking van die dialektiese teologie in Nederland (vgl. Noordmans 1981:507-689) soos tydens die etiese konferensie in Lunteren (1925) (vgl. Noordmans 1930:37-67; 1981:557-593) en neem saam met Haitjema, Miskotte en ander deel aan die gesprek met Barth wat tydens sy eerste besoek aan Nederland (1926) plaasgevind het (Haarsma 1967:4-5). Haarsma (1967) spreek hom verder soos volg uit wanneer hy stel dat Noordmans:

een bij uitstek critische geest is, een non-conformist; hij is geen man die de plooien graag glad strijkt en hij heeft geen enkele behoefte aan harmoniseren; integendeel, hij heeft een scherp oog voor de zwakke plekken in iedere constructie en weet deze feilloos bloot te leggen, geduldig en zonder onbarmhartig te zijn. (p. 13)

Noordmans se teologiese arbeid sal onvolledig wees indien nagelaat word om hier voorlopig te verwys na sy besondere bydrae op kerkregtelike gebied en derhalwe sy aandeel in die stryd om 'n nuwe kerkorde vir die Nederlandse Hervormde Kerk (vgl. Noordmans 1984).

Met verwysing na sy vermelde 'schoot der vroomheid' tydens sy erepromosie by die Universiteit van Groningen op 16 Oktober 1935, word kortliks verwys na die Réveilbeweging en sy agtergronde wat 'n bepaalde rol gespeel het. Die Friese Réveil word as moedergrond van Noordmans se lewe en werke beskou. Sy vader is gesien as representant van die Friese Réveil en dit is uit die aard van die saak die huis waarin hy grootword en begryplik dat hy daardeur beïnvloed sou word (Wassenaar 1989:39).

\section{Die Friese Réveil en sy agtergrond}

In die eerste helfte van die negentiende eeu vind ongeveer gelyktydig in verskillende lande van Europa 'n geestelike opwekking plaas wat met die gemeenskaplike naam Réveil ondervang word:

Gemeenschappelijk kenmerk was een besliste afkeer van, reactie tegen het rationalisme van de Verlichting; een verwantschap met de Romantiek met haar belangstelling voor de historie, haar nadruk op het gevoelsleven, de intuitie en de religieuze ervaring is hier onmiskenbaar. (Rasker 1981:71)

In Nederland word eweneens teen die gees van verligting en rasionalisme in die teologie wal gegooi deur beklemtoning van die inhoud van die klassieke belydenisskrifte, met nadruk op die religieuse ervaring waardeur aansluiting gevind word by die bevindelijkheid van die Nadere Reformasie. In Nederland figureer twee groepe: een in Amsterdam onder leiding van Bilderdijk en Da Costa, en 'n tweede groep in Den Haag met Groen van Prinsterer as sentrale figuur. 'Da Costa was meer dichterlijk en profetisch, Groen meer kerkelijk, confessioneel en politiek ingesteld' (Rasker 1981:75; vgl. Honders 1976).

Tog word onderskei tussen die Nederlandse en die Friese Réveil waar dit nie net gegaan het om die regte leer nie, maar ook om 'n lewende vroomheid. Die geloofslewe was metodisties, versier met ' $n$ innige gebedspraktyk wat tydens vrome samekomste in huiskamerverband met mekaar gedeel is. Réveilgenote was ook sterk gekant teen kerklike separatisme (Wassenaar 1989:5). Die mening is gestel dat die Friese Réveil afkomstig was van die Nadere Reformasie en lyne kan selfs getrek word na die piëtisme van die sewentiende en agtiende eeu. 'De verworteling in het piëtisme van de Nadere Reformatie en de invloed van het Hollandse Réveil hebben zonder meer met de herkomst van het Friese Réveil te maken' (Wassenaar 1989:6). Wassenaar is van mening dat die Friese Réveil nuwe lewe in die kerk geblaas het te midde van 'n tydsgees wat deur intellektualisme gekenmerk is.

Menslik gesproke is die invloed veral te danke gewees aan boere, gewone landsburgers en predikante. Die wêreldvreemde gesindheid werk deur en vervul latere generasies met wrok en afsku teen die wêreld van voorgeslagte en kan as 'n skadukant van die Réveil beskou word. 'De gemoedelijke vroomheid betekent te weinig, als straks de dynamisch wordende wêreld met zijn vragen komt' (Wassenaar 1989:9). Die verworteling in die piëtisme van die Nadere Reformasie en die invloed van die Hollandse Réveil het sonder meer met die herkoms van die Friese Réveil te make. 'Maar niet zodra was in het Réveil iets van het oud-gereformeerde leven ontwaakt, of men gevoelde zich in oppositie tegenover de geest die leefde in de kerkelijke besturen' (Noordmans 1984:125).

\section{Noordmans self, asook menings van enkele tydgenote}

Dit is geen enkelvoudige taak om enigsins reg aan Noordmans te laat geskied in die beperkte ruimte van 'n artikel van meegaande aard nie. Behalwe ruimte is die omvang van die 
Noordmans nalatenskap, soos gepubliseer in sy versamelde werke, van sodanige omvang dat afsonderlik aandag aan verskillende aspekte van sy teologie geskenk kan word, eerder as om te poog om volledig te wil wees in een artikel. Dit in die lig van Haarsma (1967:III) se siening dat Noordmans se denke 'van een dusdanig gehalte [is], dat één persoon de inhoud ervan niet licht zal uitputten'. Hy was boonop naas die teologie ook filosoof, fenomenoloog, asook homme de lettres (Haarsma 1967:11). In die verband word onder andere verwys na Hasselaar (1958), Paul (1959) en Haarsma (1967). Laasgenoemde is opvallend aangesien die outeur die studie as RoomsKatoliek onderneem, maar steeds besondere waardering vir Noordmans boekstaaf en poog 'de lezer deelgenoot te maken aan de vreugde en verrassing, die ik bij de studie van Noordmans' oeuvre zo dikwijls heb ervaren' (Haarsma 1967:III). Vanuit Haarsma (1967:371-378) se literatuurlys blyk die belangstelling in Noordmans wat tot op hede steeds voortgaan, tekenend van die belangstelling in sy denke. In meegaande artikel word gepoog om Noordmans so veel as moontlik self aan die woord te stel en daarom word dus van ' $n$ beperkte hoeveelheid ander literatuur gebruik gemaak.

Die besondere aard van Noordmans se teologie wat as gevolg van sy persoonlike denkkrag nie by voorbaat in vooraf gereed gemaakte vate gegiet kan word nie blyk:

door zijn kunstzinnig en op het existentiële afgestemd taalgebruik; maar - belangrijker nog - door het dienend karakter van deze theologie, die in alles het geheim van de kerk op het oog heeft. (Hasselaar 1958:5)

Hy was nie sonder meer eties, konfessioneel of dialekties nie. Hy was 'teveel confessioneel om helemaal "etisch" te zijn en te veel kohlbrïggiaan om helemaal barthiaan te zijn' (Hasselaar 1958:7). Hasselaar wys daarop dat dit die katolieke kerk is waarvoor Noordmans hom beywer het, die Una Sancta wat eerbied verg vir die ontsagwekkende tradisie van die eeue waarvan die Reformasie as ' $n$ beslissende, pneumatiese gebeurtenis in die verlede van die kerklike lewe dien.

Haarsma (1967:10) meen 'n mens kan hom 'n profeet noem wat goed bewus was van sy kerklike roeping, wat met verloop van jare meer leef en dink vanuit die komende Ryk van God. Die kerk as gestalte van die heilshandelinge van God is primêr die plek van verkondiging. Daarom klop die lewe van die kerk in die bediening van die Woord en nie in die liturgiese viering nie (Hasselaar 1958:7; vgl. Haarsma 1967:23). Hy wil as kerklike teoloog voluit in die geskiedenis van die kerk staan en daaraan deelneem. Tussen kerkvaders en Reformasie plaas hy klem op laasgenoemde wat nie leef uit die krag van die voortplanting van die waarheid nie, maar uit die waagstuk van die pneumatiese herhaling. Die verskil tussen Rome en Reformasie staan tot mekaar in die sin van voortsetting en herhaling, tot dit wat duur en insidenteel van aard is, wat vir beide kerke ' $n$ enorme struktuurverandering inhou. Hy wil van almal leer om sodoende invloed op die hele teologie uit te oefen (Hasselaar 1958:8)

Noordmans se nadenke oor kerk word nie alleen vanuit die verlede gevoed nie, maar word ook gekenmerk deur 'n eskatologiese gerigtheid. Sy dogmatiese meesterwerk Herschepping (Noordmans 1979:214-322; vgl. Noordmans 2004:391) dui op 'n kerkgedagte wat alleen vanuit die einde van die Ryk verstaan kan word.

In de geschiedenis der wereldkerk hebben wij een gelijkenis van de voleinding. Zij zal niet geleidelijk in de verheerlijking kunnen overgaan. De taak der kinderen Gods is geen scheppende. Voor de inrichting van een nieuwe hemel en een nieuwe aarde is een ander oordeel Gods nodig: het laatste oordeel. De Heilige Geest zelf is de herschepper. - Maar wel is de kerk de getuige van de kritiek van het Evangelie op de gevallen schepping. In het fragment, dat de geschiedenis der kerk is, hebben wij een onderpand des Geestes voor de wederoprichting aller dingen. (Noordmans 1979:317)

Daarom is dit nie buitengewoon dat Haarsma (1967) 'n pastoraal-ekumeniese studie aanpak en voltooi wat oor die ekklesiologie van Noordmans handel nie. Reeds in dié tyd word nie besonder optimisties oor die kerk gedink nie soos die wens van Hoekendijk (1964:48) getuig dat die ekklesiologie nie meer sal wees as 'n enkele paragraaf van die Christologie en 'n paar sinne uit die eskatologie nie.

Haarsma (1967:II) meld dat dit veral Noordmans se ‘Paulus komt en Petrus gaat' (Noordmans 1990:429-451) was wat die aanleidende oorsaak vorm waarom hy so uitvoerig oor Noordmans se ekklesiologie handel. Noordmans is van mening dat die ekklesiologie tydens die Reformasie redelik sober aan die woord gekom het wat hy meen te wyte is aan die feit dat daar geen afsonderlike leerstuk oor die kerk in die Roomse onderrig gedurende die Middeleeue aanwesig was nie. Daar die Hervormers dringend aan ander sake moes aandag gee, was die uitsprake oor die wese en kenmerke van die kerk in vele 'opzichten niet afdoende en voor de praktijk der godzaligheid tot op zekere hoogte onzeker' (Noordmans 1979:539).

Haarsma (1967:127) stel dat die uitgangspunt 'hoger dan de kerk' 'n leitmotief vorm in die ekklesiologie van Noordmans wat hy van Gunning oorneem en vervolgens interpreteer:

Voor hem ligt daarin het sterkste accent, dat het woord en de idee der kerk kunnen krijgen. Het is een hulde aan het Hoofd der kerk, Jezus Christus. Een bede om de Heilige Geest en de gemeenschap der heiligen. (Noordmans 1981:355)

Noordmans (1981:357) gaan verder met die opmerking dat om op die regte wyse in die kerk te wees daarop neerkom om 'op te klimmen tot Hem, die haar Hoofd is, Jezus Christus. Dan komt tegenover de pluriformiteit der kerk de Una Sancta naar voren'. Hy hou 'n konkrete beeld van die kerk voor wat nie stol in abstraksie nie.

Mense wat aan die kerk behoort, is lewende wesens, gelowiges en geen algemene begrippe nie:

Als hij van de Vaderlandse Kerk opklimt tot de Heilige Algemene, dan is dat geen abstractie ... Het genootschap vergaat, de kerk blijft, ... Hij denkt zich dan de kerk als toekomstig Koninkrijk ... Christus op de voorgrond stellen is de kerk zien in haar Hoofd, als een levend wezen. (Noordmans 1981:358) 
Noordmans (1981:366) wys op twee uiterstes in sy waarskuwing dat as die Una Sancta uit die kerkbegrip (kerkcredo) uitgelig word, dreig die gevaar van verroomsing, want die kerk kan die hemel nie naboots nie, maar net glo. Daarteenoor is die kerk voorwerp van geloof wat nie mag opgaan in die sedelike en maatskaplike lewe nie.

Paul (1959) wys daarop dat dit nie moontlik is om Noordmans se ekklesiologie onder een noemer tuis te bring nie:

Daarvoor is het een te bewogen ecclesiologie, bereid zich te buigen voor Hem, van Wien de evangelisten getuigen, dat Hij innerlijk met ontferming bewogen was over de schare; een ecclesiologie echter tevens, die niet barmhartiger en ruimer wil zijn dan de Heer der Kerk, en zich daarom haar stoerheid niet schaamt als het er om gaat, zich te verzetten tegen het streven, om de Kerk van Christus te verlagen tot 'een administratief genootschap van richtingen', waarbinnen 'ieder particulier inzicht het recht heeft geacht te worden te behoren tot de veelvuldige rijkdom van Christus'. (p. 149)

By die locus de ecclesia kom sy 'irreguläre theologie' ter sprake wat telkens nuwe tekens toon van 'n lewende wisselwerking tussen leer en lewe en die ontmoeting tussen Evangelie en wêreldnood. 'Veeleer worden wij hier telkens herinnerd aan de ruimte der kerk, waar het de Heilige Geest is die in al de waarheid leidt' (Paul 1959:150).

Noordmans se kerkbegrip onder bespreking kan nouliks gebeur sonder om te wys op sy besondere belangstelling in die Kerkreg en gevolglik op sy bydrae en meelewing in die Nederlandse Hervormde Kerk se stryd om 'n nuwe kerkorde wat eers realiseer op 01 Mei 1951 toe die nuwe Kerkorde ingevoer is. Dit word beaam deur Bartels (1946:voorwoord) wat die mening oor Gunning huldig:

dat deze 'alle kerkelijke eeuwen in zich droeg' ... op Noordmans zelf over te brengen. Hij heeft een invloed gehad op de theologische en kerkelijke ontwikkeling van de laatste twintig jaren als geen ander in de Nederlandse Hervormde Kerk.

Na die verwerping met 10-09 stemme van die Ontwerp-1929 tydens die Sinodale vergadering van 07-10 Januarie 1930, word die stryd om 'n belydende kerk nie daarmee gelaat nie. Die stryd vir en teen die voorstel het gedeeltelik saamgehang met die 'richtingsverschillen' wat in die Kerk geheers het. Op 10 Januarie 1930 word in Amersfoort die 'Nederlandsch Hervormd Verbond tot Kerkherstel' opgerig, gevolg deur die vereniging 'Kerkopbouw' op 16 Februarie 1931 te Utrecht. Noordmans het deel gevorm van die voorlopige moderamen wat by die geleentheid verkies is (Bartels 1946:41). By 'Kerkopbouw', soos by 'Kerkherstel', gaan dit ook om goeie kerklike prediking en die handhawing van die kerklike dissipline. Maar groter geduld word aan die dag gelê met hulle wat van die regte prediking afgewyk het (vgl. Haarsma 1967:196-197).

Noordmans se bydrae tydens die Nederlandse stryd om 'n nuwe kerkorde, word duidelik wanneer sy uitsprake en menings oor kerkorde en kerkregtelike aangeleenthede wat in die vyfde deel van sy versamelde werke gepubliseer is, geraadpleeg word (Noordmans 1984). Uit die aard van die saak word 'n keuse gemaak uit die breë verskeidenheid wat direk eweredig is met die eie, subjektiewe mening. Dalk is een van die bruikbaarste uitsprake van Noordmans, sy siening dat kerklike denke voorwaarde is vir kerkorde. Hy kwalifiseer dit met die volgende uitspraak:

Mits de eis van kerkelijk denken, dat er verband is tussen belijdenis en organisatie, word vastgehouden. Ik heb vroeger geschreven dat de kerkorde niet met dezelfde geestelijke macht uit de Schrift wordt afgeleid als het sola fide. Maar de afleiding uit de bijbel dient vastgehouden. (Noordmans 1984:444)

Hy wys daarop dat die belydenis in 'n kerkorde slegs op twee maniere kan funksioneer, naamlik as beginsel van kerkorde en as agtergrond, immanent en transendent. 'n Kerkorde is dus in al sy dele deurtrokke van die gees van die belydenis, maar die hele werklikheid wat die kerk bely, staan nog weer vry en outoritêr agter elke bepaling daarvan.

'n Kerkorde wat teen dié agtergrond die lig sien, is derhalwe 'n redelik genuanseerde dokument wat anders funksioneer as die konstitusie van 'n vereniging wat die gevolg is van die meerderheidsmening van sy lede:

Ieder artikel van een kerkelijk reglement wordt gedragen door een kerkelijke, christelijke bezinning. Het is niet geschreven voor de burgerlijke rechter, maar met het oog op de regering door de ambten in de gemeente. (Noordmans 1984:452)

Noordmans (1984:391-402) het in die jare dertig gereageer teen Brouwer (1937) wat van mening was dat vir argumente vir die ordening van die kerk, nie op die Skrif teruggegaan kan word nie:

Een beroep op de Schrift heeft zeker met exegese en historisch onderzoek te maken. Maar het gaat daarin niet geheel op. Teruggaan op de Schrift is het werk van het geloof en dat geldt niet alleen van geloofszaken in engere zin, maar ook van kerkelijke dingen. (Noordmans 1984:391-392)

Noordmans het Brouwer toegegee dat die kerkordelike afleiding uit die Skrif meer indirek as direk reglynig is, maar wat hom betref is ' $n$ kerkorde nie uiteindelik 'n praktiese aangeleentheid wat aan elkeen die vryheid gun om na goeddunke te handel nie (Noordmans 1984:394):

Maar de kerkorde mag van de Schrift toch niet worden losgemaakt. De mystieke band met de kerk des geloofs, de Una Sancta, zou daarom verbroken worden en we hielden een aardse en burgerlijke vereniging over. (Noordmans 1984:421)

Ten spyte daarvan is hy redelik stellig dat die kerk gebou is op 'Jezus Christus als enig fundament; derhalve niet op bodem, ras of bloed' (Noordmans 1984:284). Ten spyte daarvan is 'n kerkorganisasie (en derhalwe 'n kerkorde ook) 'n noodinstelling, of anders geen kerkinrigting. 'Een kerk, die te rustig en te zeker zich inricht, kan Christus' lichaam niet zijn ... Zonder ketterijen krijgt ze geen dogma en zonder misstanden geen heiligheid' (Noordmans 1984:289).

Daarom is ' $n$ kerkorde die nadering van 'n grens wat nie met dieselfde geestelike mag uit die Skrif afgelei word as die sola 
fide nie. Dit gaan gepaard met die kerkordelike strewe om so min moontlik te reglementeer. Die kerkorde word wél uit die Skrif afgelei, maar is eintlik ' $n$ poging om die menslike apparaat rondom die werk van die Heilige Gees tot die minimum te beperk (Noordmans 1984:173).

In de huidige wereldcrisis moet de kerk weer duidelijker in haar organisatie tot uitdrukking brengen, dat niet de natie maar de incarnatie haar hoeksteen is en dat haar enig fundament Jezus Christus is ... De kerk staat niet in de scheppingsorde, maar in de genadeorde. (Noordmans 1984:178)

Die vleeswording van die Woord van God is 'n kritieke begrip wat nie reglynig in die kerk voortgesit word nie. Vleeswording en versoening lê nie in mekaar se verlenging nie. 'Zij krijgt tot haar tegenhanger de uitstorting van de Heilige Geest, de Trooster' (Noordmans 1979:279).

Hoewel daar geen reglynige verband is tussen die aardse lewe van Jesus en die kerk nie, beteken dit nie dat daar geen verwantskap bestaan tussen Christologie en ekklesiologie nie. Noordmans sien die verlenging van die vleeswording van die Seun van God nie in die skepping nie, maar in die verlossing, in die vernedering van Jesus as Verlosser wat self Godverlatenheid ervaar het en tuis voel onder sondaars en siekes (Noordmans 1979:268). 'De kerk is dan misschien niet zo pompeus, niet zo indrukwekkend. Maar zij blijft in Gods handen' (Noordmans 1990:391).

Noordmans wys dus elke band tussen Christus en die kerk af wat nie deur die band van geloof loop nie. Geen voortgesette inkarnasie (vleeswording); geen voortgang van Christus deur genade en die sakramente in sy kerk nie; geen kerk wat sacramentum humanitas Christi is nie. Die enigste weg waarlangs die vleeswording heilbrengend is vir die kerk, is langs die weg van die gepredikte woord. So lê die weg oop vir die Heilige Gees, want deur sy Woord en Gees regeer Christus as Hoof sy kerk (Haarsma 1967:85).

Daarom mag die kerkorde en die denke rondom 'n kerkorde nie die weg van die parlementêre demokrasie gaan nie, waar die meerderheid besluit ongeag hoe die kerkordelike apparatuur daar sou uitsien (Noordmans 1984:181). Noordmans se waarskuwing oor die verhouding tussen kerkorde, sinodale besluite en Gees is gepas in die sin dat nie sonder meer tot die slotsom geraak moet word nie dat alle besluite (veral sinodale besluite) gesaghebbend en durend is nie, bloot omdat sodanige vergadering onder leiding van die Gees en op grond van die Skrif geneem en selfs plegtig geopen word nie. Niemand kan oor die Gees beskik nie en indien onder dié indruk verkeer word, is dit hoogstens beskikking oor 'n gees met kleinletter gespel:

Dit is het grote gevaar voor de kerk op aarde. En dit is het risico, dat God met haar neemt. Hij liet het Koninkrijk der hemelen nabijkomen, en zie, Hij moet met een kerk genoegen nemen. Het verschil is, dat de kerk altijd meer of minder zelve over de Geest beschikt. Dat is haar erfzonde, waaruit al haar verdere feilen voortkomen. Iedere kerkorde behoort eigenlijk niet anders te zijn, dan een correctie op deze grondfout. (Noordmans 1990:390)
Dit is ook die rede waarom Noordmans van mening was dat in die gereformeerde kerkreg gepoog moet word om so min as moontlik te reglementeer, omdat die kerkreg en die kerkorde 'n poging is om die menslike apparaat rondom die Heilige Gees tot 'n minimum te beperk.

In die lig van die noue relasie tussen Skrif en belydenis as normerende norme vir die kerkordelike inrigting is dit eweneens bruikbaar om Noordmans se siening oor die belydenis na vore te bring wat hy op sy unieke manier verwoord het. Noordmans (1984:458; vgl. Bartels 1946:titelblad) stel dat die belydenis 'geen stok is om te slaan nie, maar 'n staf om te gaan'. Die siening kan waarskynlik mutatis mutandis oorgedra word op die kerkorde wat inderdaad geen wetgewing wil wees wat met gesag van die burgerlike wetgewing afdwingbaar gemaak word nie (sic), maar, gesien teen die agtergronde waarteen 'n kerkorde funksioneer, om Christus wil nagekom en geleef moet word. Betrokkenes by die kerkorde van 'n bepaalde kerk is dus voortdurend uitgelewer aan die keuse tussen 'n regter van die burgerlike wetgewer en die lewende God in Jesus Christus, die Hoof van die kerk.

In sy prolegomena tot die teologie van Noordmans dui Paul (1959:32) aan dat Noordmans meer tot die 'irreguläre' as tot die 'reguläre' behoort. Hy haal Barth (1964) aan wat dit soos volg beskryf:

Unter irregulärer Dogmatik ist demgegenüber ein solches Fragen nach dem Dogma zu verstehen, ... wird sich von jener dadurch unterscheiden, dass sie nicht mit derselben Folgerichtigkeit aufs Ganze geht, ... Sie wird vielleicht aus bestimmtem geschichtlichem anlass nur ein bestimmtes Thema herausgreifen und in den Mittelpunkt rücken. (pp. 293-294)

Noordmans skryf en reageer dus na aanleiding van 'n bepaalde gebeurtenis in die kerklike lewe. Die kerkordelike stryd wat in die Nederlandse Kerk vanaf 1929 gewoed het, is daarvan 'n sprekende voorbeeld. Haarsma $(1967: 327,328)$ sê daar is bykans geen bladsy in Noordmans se geskrifte oor die kerk waar nie belanghebbende uitsprake gemaak word oor die ekklesiologie en pastorale vrae wat die kerk toentertyd besig gehou het nie. Hy beskou Noordmans as 'een theologisch artiest' wat selde onder teoloë gevind word en die vraag kom na vore of 'n dialoog met Noordmans überhaupt moontlik is.

Haarsma (1967:329) is van mening dat die woorde 'hoër as die kerk' wat Noordmans aan Gunning ontleen het, as uitgangspunt van sy kerkleer beskou kan word. Die kerk vul die ruimte tussen die nabyheid van die ryk van God in die openbare lewe van Jesus en sy koms aan die einde van die tyd.

Dezelfde idee werkt Noordmans uit, wanneer hij spreekt over Christus als Hoofd der kerk. Hij en Hij alleen regeert de kerk door Woord en Geest ... De heerschappij van Christus door zijn Geest en Woord werkt ook door in de wijze waarop Noordmans staat tegenover belijdenis en dogma. (Haarsma 1967:330-331)

Die uitgangspunt 'hoër as die kerk' word veral met betrekking tot die Gees uitgewerk. Die kerk is 'n kerk van sondaars, 
semper purificanda en slegs heilig omdat die Gees van God die kerk telkens en voortdurend heilig.

'n Verdere uitgangspunt wat Haarsma $(1967: 337,342)$ noem, is die van 'verder as die kerk' wat die kerk van selfoorskatting bewaar en laat besef dat die kerk slegs 'n noodinstelling is, wat niks van homself nie maar alles van Christus, sy Hoof en van die Heilige Gees as herskepper verwag. Dit herinner die kerk ook aan sy taak in die wêreld. En tog word die kerk daaraan herinner dat hy homself nie moet onderskat nie. Inteendeel, die kerk is kerk van Jesus Christus die Hoof van sy kerk wat onder leiding van die Gees kerk in die wêreld is.

In sy beoordeling van Noordmans se teologie maak Paul (1959) die opmerking dat die soteriologiese gesigspunt allesbeheersend is. Dit is 'n uitgesproke theologia crucis, 'n teologie vanuit die midde wat kring rondom die heilsgeheim van die Middelaar tussen God en mens, Jesus Christus.

De soteriologische aanvat van Noordmans' theologie wordt niet alleen gerechtvaardigd door de gang van het apostolische Credo, maar ook door die van het heilsgebeuren zelf: de openbaring van de Drie-enige God. (pp. 220-221)

Hasselaar (1958:9) stel dat Noordmans 'n kerklike teoloog is, 'omdat zijn theologie in de grond der zaak niet anders wil zijn dan een ontvouing van hét dogma der kerk, namelijk de belijdenis van de drie-enige God'. Die skerpheid van Noordmans se kerkregtelike insig met betrekking tot die presbiteriale kerklike regering (presbiteriaal-sinodaal) blyk uit sy vergelyking van die pous en die ouderling: 'Toen Calvijn op het bord de pion van de ouderling trok, zette hij daarmee de paus schaakmat' (Noordmans 1984:396).

In die verbygaan word ook daarop gewys dat Noordmans nie net in die kerkregtelike debat nie, maar veral met prof. G. van der Leeuw (1890-1950) ernstig deelgeneem het aan die diskussie oor die liturgie, waarin hy eweneens 'n besondere bydrae gelewer het en deur kollegas daarin toegegee is (Haitjema 1940:173; vgl. Noordmans 1986:45-344).

\section{Slotopmerkings}

Een van die mees besondere bydraes van Noordmans in kerkordelike sin is sy opmerking dat kerklike orde, kerklike denke verg. Dit is van wesenlike belang wat krities beskou geldig en bruikbaar is, selfs in die huidige tydsgewrig en daarna. Die uitgangspunt word ondersteun deur sy Christologies-pneumatiese fundering van sy kerkbegrip. Jesus Christus is Hoof van die kerk wat in die ruimte tussen hemelvaart en wederkoms inwig tot troos vir die kerk wat weerstand moet bied teen die wanorde, gelei en bewaar deur die Gees wat die waarborg is van die erfdeel van gelowiges. Ekklesiologies sou sy kerkbegrip tipeer kan word as 'n Christologiese ekklesiologie wat in die verlenging staan van die Gees. 'n Waarskuwing aan die kerk is gepas dat nie oor die Gees beskik word nie en dat 'n kerkorde 'n noodmaatreël is as korreksie op dié grondfout van die kerk. Noordmans se siening oor die belydenis wat soos 'n staf is om te gaan en nie in 'n slaanstok moet ontaard nie, is eweneens bruikbaar en kan óók op die kerkorde van toepassing gemaak word. Daarom staan dit bekend as 'n orde, die gebruiklike begrip in Nederland in gebruik sedert die Sinode van Middelburg, 1581 (Jansen 1952:7).

Noordmans se trinitariese teologie wat as onderbou funksioneer vir sy Christologiese ekklesiologie, gee sin aan 'n kerkorde en verwoord die rede waarom van ampsdraers en lidmate in die kerk verwag kan word om die kerkorde om Christus wil, na te leef. Kerklike verskille behoort dus nie verder te vorder as 'n openhartige broederlike gesprek nie.

\section{Erkenning Mededingende belange}

Die outeur verklaar dat hy geen finansiële of persoonlike verbintenis het met enige party wat hom nadelig kon beïnvloed het in die skryf van hierdie artikel nie.

\section{Literatuurverwysings}

Bartels, H., 1946, Tien jaren strijd om een belijdende kerk, Van Stockum \& Zoon, Den Haag.

Barth, K., 1964, Die Kirchliche Dogmatik, vol. 1/1, EVZ-Verlag, Zürich.

Brouwer, A.M., 1937, De kerkorganisatie der eerste eeuw en wij, Bosch \& Keuning, Baarn.

Haarsma, F., 1967, Geest en kerk, Bosch \& Keuning, Baarn.

Hasselaar, J.M., 1958, $\operatorname{Dr}$ O. Noordmans: Hoofdmomenten van zijn theologie, Boekencentrum, 's-Gravenhage.

Haitjema, T.L., 1940, 'Schrift, belijdenis en kerkorde', Onder eigen vaandel 15 173-193.

Hoekendijk, J., 1964, De kerk binnenste buiten, Ten Have, Amsterdam.

Honders, A.C., 1976, 'Op zoek naar de theologische struktuur van het Réveil', Kerk en Theologie 27, 1-17.

Jansen, J., 1952, Korte verklaring van de Kerkorde, Kok, Kampen.

Noordmans, O., 1930, Geestelijke perspektieven, H.J. Paris, Amsterdam.

Noordmans, O., 1979, Verzamelde werken, Deel 2, Kok, Kampen.

Noordmans, O., 1981, Verzamelde werken, Deel 3, Kok, Kampen.

Noordmans, O., 1984, Verzamelde werken, Deel 5, Kok, Kampen.

Noordmans, O., 1986, Verzamelde werken, Deel 6, Kok, Kampen.

Noordmans, O., 1988, Verzamelde werken, Deel 4, Kok, Kampen.

Noordmans, O., 1990, Verzamelde werken, Deel 8, Kok, Kampen.

Noordmans, O., 1999a, Verzamelde werken, Deel 9A, Kok, Kampen.

Noordmans, O., 1999b, Verzamelde werken, Deel 9B, Kok, Kampen.

Noordmans, O., 2004, Verzamelde werken, Deel 10, Kok, Kampen.

Odendal, F.F. \& Gouws, R.H. (reds.), 2005, HAT, Verklarende handwoordeboek van die Afrikaanse taal, Maskew Miller Longman, Kaapstad.

Paul, G.J., 1959, Schepping en koninkrijk, Veenman \& Zonen, Wageningen.

Rasker, A.J., 1981, De Nederlandse Hervormde Kerk vanaf 1795, Kok, Kampen.

Wassenaar, J.D.Th., 1989, 'De schoot der vroomheid: O. Noordmans' biografische achtergrond in het bijzonder zijn verworteling in het Friese Reveil', doctoraalscriptie voor de faculteit der godgeleerdheid, Rijksuniversiteit te Utrecht. 